\title{
$403 \mathrm{X}-\mathrm{FEM}$ によるく離を有する複合材料積層板の座屈解析
}

\section{Buckling analysis of composite laminates with delamination using X-FEM}

\author{
$\bigcirc$ 学 近藤 幸弘（上智大・院） \\ 正 長嶋 利夫、正 末益 博志（上智大・理工）
}

\begin{abstract}
Yukihiro KONDO, Graduate School, Sophia University, 7-1 Kioicho Chiyoda-ku Tokyo, 102-8554, Japan Toshio NAGASHIMA, Department of Mechanical Engineering, Sophia University

Hiroshi SUEMASU, Department of Mechanical Engineering, Sophia University
\end{abstract}

Key Words: X-FEM, Buckling, Composite laminates, Delamination

\section{1.はじめに}

複合材料積層板はその材料特性上、外部からの衝撃によっ て板内部に、トランスバースクラックや層間はく離などの損 傷が容易に発生する。これらの損傷は積層板の圧縮強度を著 しく低下させる要因となることが知られている。したがって、 圧縮強度低下の原因である衝撃損傷のメカニズムを明らか にすることは重要である. 衝撃損傷によって積層板に生じる 層間はく離は一般に複雑な形状になり、はく離の発生位置も 一箅所であるとは限らないのでそのモデル化は難しくなる. 有限要素法（Finite Element Method:FEM）は連続体を対象 とした離散化手法であるため、はく離のような不連続領域を モデル化するためには特殊な扱いが必要になる，具体的には、 はく離面の接触を表わすためのインターフェイス要素や、は く離先端近傍の応力場の特異性を表わせる特殊要素などが 利用されている．したがって、はく離などの不連続面をモデ ル化するためには、要素の境界を不連続面の形状に適合させ る必要がある.また、はく離の伝播をシミュレートする場合、 計算ステップ毎にはく離先端の位置が変化していくので、は く離が伝播するたびにはく離面を考庫してメッシュを再分 割しなくてはならない。

一方で、Belytschkoら[1]が提案した拡張有限要素法 (eXtended-Finite Element Method：X-FEM) は構造物にお けるき裂や自由表面などの不連続面を、内挿関数で近似表現 できる、具体的には、変位場の特性を表現できる基底関数 (エ ンリッチ関数）が、従来のFEMの内挿関数に局所的に付加さ れている。このようにX-FEMはき裂やはく離などの不連続面 を含む構造物をモデル化する場合でむ要素の形状を不連続 面の形状に適合させる必要がない.

著者らは、衝撃損賃を受ける複合材料積層板の強度評価の 一環として、X-FEMを層間はく離を有する複合材料積層板の 解析に適用することを試みている[2] [3]. 本稿では、X-FEM による複合材料積層板の線形座屈固有值解析を実施し、その 解析精度の検討を行う。

\section{2. $\mathrm{X}-\mathrm{FEM}$}

X-FEMで、はく離をモデル化する場合の内挿関数は次式で 表わされる.

$$
\begin{aligned}
& \mathbf{u}^{h}(\mathbf{x})=\sum_{I=1}^{m} N_{l}(\mathbf{x}) \mathbf{u}_{l}+\sum_{l \in C} N_{I}(\mathbf{x}) \sum_{k=1}^{4} \gamma_{k}(\mathbf{x}) \mathbf{a}_{I}^{k}+\sum_{I \in J} N_{I}(\mathbf{x}) H(\mathbf{x}) \mathbf{b}_{l}(2) \\
& \text { ここにN }
\end{aligned}
$$
は要素を構成する節点数、Cは、はく離先端近傍の変位につ いての漸近解の特性を考虐する節点の集合、Jは、はく離面 上の変位の不連続性を考慮する節点の集合、 $\mathrm{u}_{I} 、 \mathrm{a}_{I}{ }^{K} 、 \mathrm{~b}_{I}$ は節

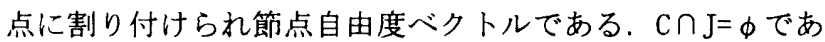
る.また、 $\gamma_{\mathrm{i}}(\mathrm{i}=1,4)$ は、はく離先端の変位場の漸近解を表 わす基底関数、 $H(\mathrm{x})$ は、はく離近傍での変位の不連続性を 表わすへビサイド(Heviside) 関数である.

基底関数 $\gamma_{i}$ として次式が用いられる.

$$
\gamma_{1}=\sqrt{r} \cos \left(\frac{\theta}{2}\right), \gamma_{2}=\sqrt{r} \sin \left(\frac{\theta}{2}\right), \gamma_{3}=\sqrt{r} \sin \left(\frac{\theta}{2}\right) \sin \theta, \quad \gamma_{4}=\sqrt{r} \cos \left(\frac{\theta}{2}\right) \sin \theta^{(3)}
$$

ここに $r 、 \theta$ は、はく離先端位置を原点とする極座標であ る. 式(3)に示された基底関数は、均質材中のき裂先端の変 位場についての漸近解を再構成することが可能である.

\section{3. 数值解析例}

Figure 1のように層間はく離を有する複合材料積層板に压 縮荷重を与えた場合の線形座屈固有值解析を実施した. 解析 対象は炭素繊維強化複合材料 $\left(\mathrm{E}_{\mathrm{L}}=142 \mathrm{GPa} 、 \mathrm{E}_{\mathrm{T}}=10.8 \mathrm{GPa}\right.$ 、 $\left.\mathrm{G}_{\mathrm{LT}}=5.49 \mathrm{GPa} 、 \mathrm{G}_{\mathrm{TT}}=3.72 \mathrm{GPa} 、 v_{\mathrm{LT}}=0.3 、 \nu_{\mathrm{TT}}=0.45\right)$ から成る、 一辺が $100 \mathrm{~mm}$ 、板厚が $1 \mathrm{~mm}$ の正方形板を想定した。積層数は 8 層、積層構成は $[45 /-45 / 0 / 90] \mathrm{s}$ とした。板の中央面より $0.25 \mathrm{~mm}$ の位置（-45度層と0度層の間）に、矩形状または円形 状の2種類の層間はく離を設定した。円形状はく離は矩形状 はく離と同じ面積とした.

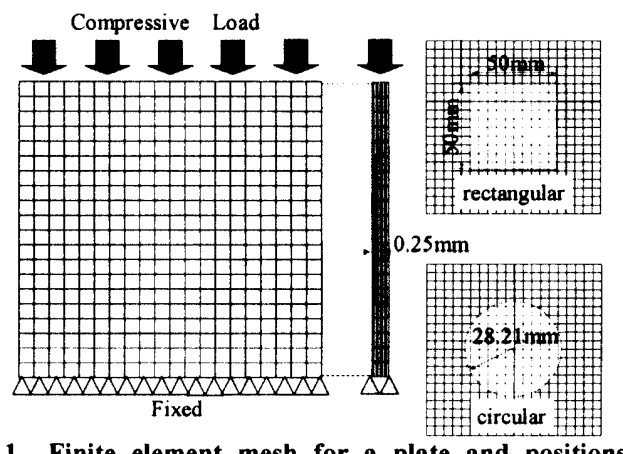

Figure 1 Finite element mesh for a plate and positions of a rectangular and a circular delaminations

〔No.02-2〕 日本機械学会第 15 回計算力学講演会講演論文集〔2002-11.2 4 ・鹿児島市〕 
はく離の無い積層板を低次のソリッド要素（8節点要素）

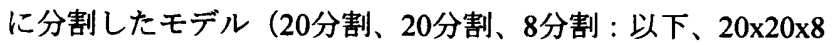
と記す）と高次のソリッド要素（20節点要素）に分割したモ デル (20x20x8) と低次のシェル要素（4節点要素）に分割し たモデル（20x20）の3通りの解析をFEMを用いて実施した. 解析結果をTable 1に示寸.

Figure 2にX-FEM解析において、矩形状のはく離をモデル 化する場合の節点属性の付与方法を示す. Model-Aでは「J」 で示された節点において、はく離内部の変位の不連続性を表 わす基底関数の自由度がエンリッチされる．また、Model-B では「C」で示された節点において、はく離先端近傍の変位 場を再構成できる基底関数の自由度がエンリッチされる。

矩形状のはく離をダブルノードでモデル化した場合の FEM解析結果、およびX-FEM解析結果をTable 2に示した. X-FEMではFEMと比較するために、節点属性「J」を用いた 場合、および節点属性「J」「C」の両方を用いた場合の2通 りの解析を実施した。

円形状はく離を想定した場合の座屈固有値解析結果を Table 3に示した. FEM解析においては低次のソリッド要素 (要素数 : 6,032 、節点数 : 7,358) および高次のソリッド要 素（要素数：6,032、節点数 : 28,094）を用い、はく離はダ ブルノードでモデル化した．また、X-FEM解析においては低 次のソリッド要素 $(20 \times 20 \times 8$ 、要素数: 3,200 、節点数 : 3,969$)$ を用い、はく離の節点属性は「J」「C」の両方を用いてモデ ル化した．その際のFEM解析におけるメッシュ分割図と X-FEM解析の節点属性の与え方をFigure 3に示した.

矩形状のはく離を有する積層板についての解析結果より X-FEMで節点属性を付与してはく離をモデル化しても、従来 のFEM解析による解析結果とほほ整合が取れることが示さ れた．また、はく離のモデル化はX-FEMを用いたほうがは るかに容易であった．円形状のはく離を有する積層板につい ては、FEMによる解析結果とX-FEMによる解析結果の整合が 取れていないが、これはX-FEMに用いたモデルのメッシュ分 割がFEM解析に用いたモデルのメッシュ分割に比べて粗す ぎたためである，とくに、2次の座屈モードを比較すると、 高次要素を用いたFEM解析では、はく離部の局所座屈が見ら れるが、低次要素を用いたFEM解析とX-FEM解析では板全体 の座屈しか見られない.この件に関しては今後X-FEM解析モ デルのメッシュ分割をより細かくし、再度FEM解析と比較す る必要がある。

\section{4. おわりに}

本稿では、複合材料積層板に矩形状および円形状のはく離 を想定し、圧縮荷重を与えた場合の座屈固有値解析をFEMと X-FEMの2種類の方法を用いて実施し、X-FEMの解析精度の 検証を試みた。今後は、積層板中の層間はく離の数を増やし、 任意形状のはく離を想定した座屈固有値解析をX-FEMを用 いて実施する予定である。

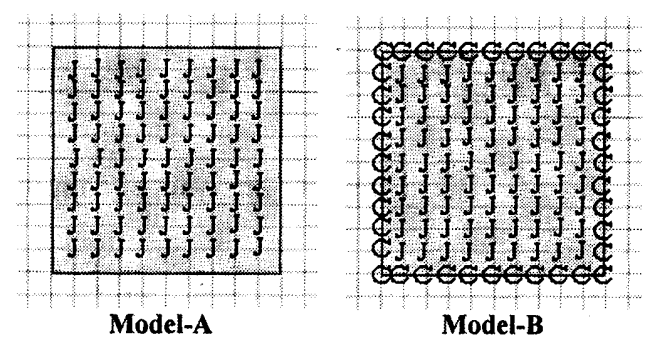

Figure 2 Modeling of a rectangular delamination using

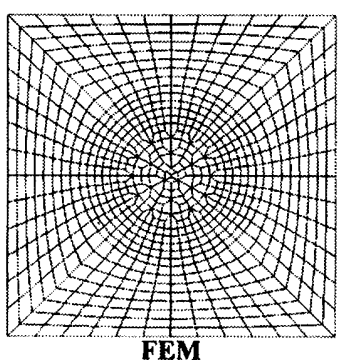

FEM

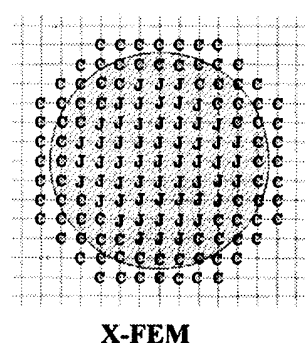

X-FEM
Figure 3 Modeling of a circular delamination

Table 1 Calculated buckling load of a laminated plate without delamination

\begin{tabular}{|c|c|c|c|}
\hline \multirow{2}{*}{ order } & \multicolumn{2}{|c|}{ Solid } & Shell \\
\cline { 2 - 4 } & 8node & 20node & 4node \\
\hline 1 & 73.005 & 72.715 & 72.892 \\
\hline 2 & 653.62 & 648.44 & 655.27 \\
\hline 3 & 1182.6 & 1168.3 & 1174.3 \\
\hline
\end{tabular}

Table 2 Calculated buckling load of a laminated plate with a rectangular delamination

\begin{tabular}{|c|c|c|c|}
\hline \multirow{2}{*}{ order } & FEM & \multicolumn{2}{|c|}{ X-FEM } \\
\cline { 2 - 4 } & Double Node & Model-A & Model-B \\
\hline 1 & 72.088 & 72.125 & 71.640 \\
\hline 2 & 623.27 & 626.33 & 620.49 \\
\hline 3 & 884.91 & 915.81 & 924.25 \\
\hline
\end{tabular}

Table 3 Calculated buckling load of a laminated plate with a circular delamination

\begin{tabular}{|c|c|c|c|}
\hline \multirow{2}{*}{ order } & \multicolumn{2}{|c|}{ FEM } & X-FEM \\
\cline { 2 - 4 } & 8node & 20node & 8node \\
\hline 1 & 73.654 & 71.899 & 71.503 \\
\hline 2 & 628.20 & 541.44 & 631.03 \\
\hline 3 & 713.23 & 622.86 & 1145.5 \\
\hline
\end{tabular}

\section{参考文献}

1) Moes, N., Dolbow, J. and Belytschko, T., A finite element method for crack growth without remeshing, Int. j. numer. Method eng., 46 (1999), 131-150.

2) Nagashima, T., Stress Analysis of Composite Materials using X-FEM, 43rd AIAA/ASME/ASCE/AHS/ASC Structures, Structural Dynamics and Materials Conference (SDM), Denver, Colorado (2002-4).

3) 長嶋・末益 : X-FEMによる積層板構造解析、第44回構造強度に関 する講演会講演集 (2002-7), 57-59. 